\title{
EkoMiasto\#Społeczeństwo
}

Zrównoważony, inteligentny i partycypacyjny rozwój miasta

pod redakcją

Aleksandry Nowakowskiej, Zbigniewa Przygodzkiego, Agnieszki Rzeńcy 
http://dx.doi.org/10.18778/7969-221-7.02

Monika Zadrożniak*

\section{JAKOŚĆ ŻYCIA W MIEŚCIE}




\subsection{Jakość życia - istota i złożoność pojęcia}

Jakość życia budzi zainteresowanie szeregu nauk, m.in.: ekonomii, socjologii, psychologii, etyki czy filozofii. Kontrowersje wokół terminologii tego pojęcia determinują przede wszystkim jego złożoność i różnice w interpretacji jej podstawowych składowych. Jako kategoria pojęciowa pojawiła się po Il wojnie światowej, początkowo bowiem kojarzono ją z dobrostanem materialnym jednostki, potem rozszerzono o wartości niematerialne. W latach 50. A. Campbell utożsamiał dobre życie z konsumpcją, uzależniając je od stanu posiadania. W 1973 r. wskazywano już na elementy osobistej satysfakcji, w 1975 r. - dołożono konieczny warunek szczęścia [Rokicka, 2013, s. 166].

Istotą i podstawą definiowania jakości życia jest system wartości oraz hierarchia potrzeb. Powszechnie obowiązujący system wartości definiowany jako zbiór norm wyznacza hierarchię potrzeb (piramida potrzeb według A. Masłowa). Kształtuje on zachowania ekonomiczne i społeczne ludzi, wyznaczając preferowane style życia, modele konsumpcji, stosunek do luksusu czy wreszcie wyznacza społecznie akceptowalną i pożądaną jakość życia. Stąd też różne definicje jakości życia jako kategorii pojęciowej: definicje egzystencjalne, definicje związane z zaspokojeniem potrzeb wyższego rzędu, określanych poprzez poziom samorealizacji itp. oraz definicje środowiskowe.

Definicje egzystencjalne związane są z zaspokojeniem podstawowych potrzeb, takich jak stan posiadania, aktualna sytuacja społeczno-ekonomiczna, m.in.: „jakość życia to godne warunki do życia w społeczeństwie. Należą do nich dobra materialne, poczucie równości i sprawiedliwości, równe szanse w edukacji i zatrudnieniu, sprawiedliwy podział dochodu, humanizacja pracy, itp." [Soziologie-Lexikon, 1991, s. 364].

Definicje związane z zaspokojeniem potrzeb wyższego rzędu, określane są poprzez poziom samorealizacji, aspiracji zawodowych i życiowych, m.in.: „jakość życia to ogólny dobrobyt, obejmujący materialny i społeczny status, samopoczucie psychiczne i osobisty rozwój jednostki" [Galloway, 2006, s. 111].

Definicje środowiskowe związane są z dostępem do określonej jakości środowiska przyrodniczego i szeroko rozumianego środowiska społeczno-gospodarczego, m.in.: „jakość życia obejmuje zadowolenie jednostki, dobrobyt materialny, zdrowe ekologicznie środowisko naturalne, możliwość kształtowania własnego stylu życia lub integracji jednostki w ramach społeczeństwa” [Famielec, 1999, s. 17] czy „jakość życia to idywidualne postrzeganie pozycji jednostki w środowisku, w którym ona żyje, oceniane przez pryzmat przyjętych przez niż celów, aktualnego stanu zdrowia fizycznego i psychicznego, jej niezależności i przekonań oraz panujących stosunków społecznych" [WHOQOL, 1997, s. 1].

Złożoność pojęcia „jakość życia” wynika bezpośrednio z jej podziału na czynniki subiektywne (jakościowe, niemierzalne) - indywidualnie oceniane z perspektywy jednostki i obiektywne (ilościowe, mierzalne) - dające obraz sytuacji ekonomicznej na podstawie „twardych” wskaźników. Dalej rozpatruje się ją w kategoriach dobrobytu, poziomu życia (w sensie obiektywnym, mierzalnym) i dobrostanu, jakości życia (w sensie subiektywnym i jakościowym). Podziału jakości życia na te podstawowe obszary wraz z określeniem ich w dwóch ujęciach: subiektywnym i obiektywnym prezentuje model zaproponowany przez E. Allardta (tab. 2.1).

Wieloaspektowość jakości życia powoduje powstanie szeregu interpretacji i definicji ze względu na określone kryterium (tab. 2.2). Z poziomu szczegółowości to: cząstkowa jakość życia - stanowi ocenę jedynie wycinka „życia”, skupia się wokół jednej ze sfer „życia”, np. życie rodzinne, sytuacja materialna, zdrowie itd. Z kolei globalna jakość życia - prezentuje całościowe pole obserwacji wszystkich sfer „ży- 
cia" funkcjonowania (sferowanie jakości życia m.in. według 6 sfer Kolmana, 13 sfer Campbella - Borys, 2004, s. 9).

Zrównoważona jakość życia oznacza równowagę pomiędzy jakością typu: „mieć”, „być”, „kochać”, za którymi stoją w równym stopniu rozwój fizyczny (materialny), psychiczny i duchowy człowieka: 2-modułowa: gdy następuje równoważenie między jakością typu „mieć” (having) i jakością typu „być” (being) oraz 3-modułowa: gdy następuje równoważenie między jakością typu „mieć” (having), „być” (being), „kochać” (loving). Z kolei niezrównoważoną jakością życia jest stan, w którym równowaga pomiędzy jakością typu „mieć”, „,być” lub „kochać” zostaje zaburzona, np. gdy obiektywnej ocenie poziomu zaspokojenia potrzeb materialnych typu „mieć” nie towarzyszy równie dobra ocena jakości życia typu „być”, zatem można być bogatym i jednocześnie nieszczęśliwym.

Tabela 2.1. Model jakości życia zaproponowany przez E. Allardta

\begin{tabular}{|l|l|l|}
\hline \multicolumn{1}{|c|}{ Obszar } & \multicolumn{1}{|c|}{ Ujęcie obiektywne } & \multicolumn{1}{c|}{ Ujęcie subiektywne } \\
\hline $\begin{array}{l}\text { Posiadania (having) potrzeby } \\
\text { materialne = jakość życia typu } \\
\text { „mieć” }\end{array}$ & $\begin{array}{l}\text { Poziom życia, } \\
\text { uwarunkowania } \\
\text { środowiskowe }\end{array}$ & $\begin{array}{l}\text { Niezadowolenie/ } \\
\text { satysfakcja z warunków życio- } \\
\text { wych }\end{array}$ \\
\hline $\begin{array}{l}\text { Miłości (loving) potrzeby } \\
\text { społeczne = jakość życia typu } \\
\text { „kochać” }\end{array}$ & $\begin{array}{l}\text { Relacje } \\
\text { międzyludzkie }\end{array}$ & $\begin{array}{l}\text { Nieszczęście/ } \\
\text { szczęście w relacjach } \\
\text { z innymi }\end{array}$ \\
\hline $\begin{array}{l}\text { Istnienia (being) } \\
\text { potrzeby rozwoju = jakość życia } \\
\text { typu „być” }\end{array}$ & $\begin{array}{l}\text { Stosunek jednostki } \\
\text { do społeczeństwa } \\
\text { i środowiska } \\
\text { przyrodniczego }\end{array}$ & $\begin{array}{l}\text { Alienacja (wyobcowa- nie)/ } \\
\text { poczucie akceptacji społecznej } \\
\text { Rozwój osobisty }\end{array}$ \\
\hline
\end{tabular}

Źródto: Łuszcryłk, 2013, s. 103; Ostasiewicz, 2004, s. 42-43.

Określenie sytuacji życiowej w zależności od punktu widzenia jednostki/grupy wskazuje na indywidualną jakość życia - ocenę poszczególnych sfer życia jednostki w ujęciu subiektywnym i obiektywnym oraz zbiorową jakość życia, która jest uogólnieniem indywidualnych (jednostkowych) jakości życia dotyczących określonej grupy społecznej, np. mieszkańców dzielnicy.

Badania jakości życia prezentują dwie kategorie: bezpośrednią jakość życia stanowiącą wynik badań ankietowych oraz pośrednią, wynikającą ze statystyki publicznej, określaną za pomocą wskaźników, np. 1 lekarz na 1000 mieszkańców.

System wartości, który określa pozycję człowieka jako podmiotu rozwoju i ważność jego potrzeb wobec środowiska przyrodniczego, generuje aksjologiczną jakość życia: antropocentryczną jakość życia, gdzie potrzeby człowieka są najważniejsze, oraz holistyczną (całościową) jakość życia - podmiotem jest całość istot żywych.

Jakość życia to zatem ogół warunków życia jednostki/grupy, kształtujących się w wymiarach społecznym, gospodarczym, środowiskowym i świadomościowym rozwoju określonej przestrzeni (jednostki terytorialnej, miasta), które w ujęciu obiektywnym i subiektywnym (ilościowym i jakościowym) stanowią o poczuciu zaspokojenia potrzeb i spełnienia aspiracji życiowych w danym miejscu i czasie. 


\begin{tabular}{|c|c|c|}
\hline \multicolumn{2}{|c|}{ Definicje jakości życia } & \multirow{2}{*}{$\begin{array}{l}\text { Kryterium } \\
\begin{array}{l}\text { Sposób charakterystyki jakości } \\
\text { życia }\end{array}\end{array}$} \\
\hline $\begin{array}{l}\text { Ujęcie praktyczne, czyli war- } \\
\text { tościująco-oceniające, daje moż- } \\
\text { liwość porównań jakości życia } \\
\text { w kategoriach lepsza - gorsza }\end{array}$ & $\begin{array}{l}\text { Ujęcie teoretyczne, czyli } \\
\text { niewartościujące, opisowo-wy- } \\
\text { jaśniające - opisuje jakość życia, } \\
\text { wskazując jedynie na różnice, } \\
\text { nie daje możliwości porównania }\end{array}$ & \\
\hline $\begin{array}{l}\text { Subiektywna i obiektywna } \\
\text { jakość życia } \\
\text { W ujęciu praktycznym wyróżnić } \\
\text { można następujące kategorie } \\
\text { definicji jakości życia: } \\
\text { a) definicje egzystencjalne, } \\
\text { b) definicje związane } \\
\text { z poziomem samorealizacji, } \\
\text { c) definicje środowiskowe }\end{array}$ & $\begin{array}{l}\text { Globalna i cząstkowa jakość } \\
\text { życia }\end{array}$ & Poziom percepcji \\
\hline \multicolumn{2}{|c|}{ Indywidualna i zbiorowa (grupowa) jakość życia } & $\begin{array}{l}\text { Punkt widzenia jednostki bądź } \\
\text { grupy }\end{array}$ \\
\hline \multicolumn{2}{|c|}{ Bezpośrednia i bezpośrednia jakość życia } & $\begin{array}{l}\text { Wynikająca ze sposobu pro- } \\
\text { wadzenia badań }\end{array}$ \\
\hline \multicolumn{2}{|c|}{ Zrównoważona i niezrównoważona życia } & $\begin{array}{l}\text { Korelacja między jakościami } \\
\text { życia typu „mieć”, „być”, „kochać” }\end{array}$ \\
\hline \multicolumn{2}{|c|}{$\begin{array}{l}\text { Aksjologiczna: antropocentryczna, holistyczna (całościowa), ekocen- } \\
\text { tryczna jakość życia }\end{array}$} & System wartości \\
\hline
\end{tabular}

Źródto: opracowanie własne na podstawie Borys, Rogala, 2008; Żylič, 2007; Leźnicki, 2011; Rokicka, 2013; Diagnoz̨a spotec:na, 2007.

Obecnie można wyróżnić pięć głównych nurtów zainteresowań jakością życia

[Rokicka, 2013, s. 161]:

1) Skupiający się na ochronie środowiska przyrodniczego (wskazuje konsekwencje postępu cywilizacji dla środowiska, zdrowia i jakości życia człowieka w związku z hałasem, zanieczyszczeniem wód czy powietrza itp.).

2) Związany z pomiarem zdrowia (w naukach medycznych jakość życia uwarunkowana stanem zdrowia).

3) Odnoszący się do procesów urbanizacji (niekorzystne skutki rozwoju naukowo-technicznego na obszarach zurbanizowanych, m.in.: wadliwe planowanie miast, mieszkań itp.). 
4) Oparty na motywach społeczno-psychologicznych (negatywne konsekwencje rozwoju cywilizacyjnego dla jednostki i życia społecznego: wyobcowanie społeczne, osamotnienie itp.).

5) Koncentrujący się na ekonomicznym aspekcie jakości życia (jakość życia jednostki, społeczności lokalnej, regionalnej i kraju).

Istotny z punktu widzenia tematu jakość życia w mieście jest nurt odnoszący się do procesów urbanizacji i tworzenia miejskiej przestrzeni publicznej, satysfakcjonującej mieszkańców miast zarówno w sensie warunków materialnych, jak i zaspokojenia potrzeb wyższego rzędu, możliwości rozwoju osobistego i zawodowego. Okazuje się bowiem, że sama dostępność do dóbr i usług nie stanowi jeszcze o pożądanym poziomie zaspokojenia ważnych, z punktu widzenia jednostki czy grupy, potrzeb i aspiracji. Przykładem może być dostęp do infrastruktury telekomunikacyjnej, który w latach 90. stanowił o wysokiej jakości życia. Ostatecznie jednak to rozwój wyprzedził potrzeby, współcześnie o jakości życia decyduje poziom zaspokojenia potrzeb z pomocą możliwości, jakie daje powszechny dostęp do Internetu czy telefonii komórkowej.

\subsection{Jakość życia - ujęcie obiektywne i subiektywne}

W kategorii „jakość życia” wyróżnia się czynniki obiektywne, takie jak: dobrobyt materialny, usługi społeczne i dostęp do infrastruktury i czynniki subiektywne, tj. indywidualne odczucia psychiczne jednostek, m.in.: zadowolenie, szczęście czy satysfakcja.

Ujęcie subiektywne (indywidualny punkt widzenia jednostki) utożsamia jakość życia z poziomem odczuwanej satysfakcji z życia jako całości i poszczególnych jej składowych. „Jakość życia obejmuje te potrzeby jednostki, które ta uważa za najistotniejsze dla swego życia (wartości egzystencjalne) oraz opinie jednostki na temat poziomu zaspokojenia tych potrzeb. Jest to kategoria subiektywna, a nawet podwójnie subiektywna: subiektywny jest sam fakt uznania pewnej grupy potrzeb za wartości egzystencjalne a dalej subiektywnie (indywidualnie) kształtują się oceny stopnia ich zaspokojenia" [Kaleta, 1985, s. 10-11].

W podejściu obiektywnym z kolei jakość życia determinują obiektywne warunki życia całej zbiorowości. Obiektywny wymiar jakości życia należy rozumieć jako standard życia, warunki materialne (bytowe). Nie ma jednak wyraźnej granicy rozróżniającej czynniki subiektywne i obiektywne, być może ze względu na szczególny społeczno-ekonomiczny wymiar jakości życia. Równoczesne prowadzenie badań subiektywnych i obiektywnych wiąże się zatem z ich wzajemnymi relacjami. Jednocześnie nie można założyć, że obiektywnej poprawie jakości życia zawsze towarzyszą odczucia subiektywnej poprawy jakości życia i odwrotnie (przykłady: „bogaty i nieszczęśliwy” czy „szczęśliwy ale biedny”. Wskaźniki subiektywne dają obraz odczuwania własnej pozycji materialnej, warunków życia, informację o tym, na ile indywidualne oceny dotyczące wymiaru obiektywnego są zgodne z odczuciami, odzwierciedlają panujące nastroje społeczne (przykład: „bogatym żyje się lepiej”).

\subsubsection{Poziom życia a jakość życia}

W tym miejscu należy wyjaśnić pewne różnice w używanych zamiennie pojęciach: „poziom życia” - charakteryzujący czynniki materialne, mierzalne a „jakość życia" - pojęcie szersze, obejmujące także te niematerialne. Rozróżnienie polega na traktowaniu poziomu życia jako stopnia realizacji bądź zaspokojenia różnych dla różnych jednostek potrzeb życiowych. Jakość życia to natomiast sposób, w jaki te potrzeby będą zaspokajane. Na ten sposób będą mieć wpływ także: wybór celów ży- 
ciowych, zaspokajając przy tym określone potrzeby życiowe, ważniejsze i mniej ważne zdaniem określonej jednostki [Gałęski, 1977]. Subiektywna ocena jakości życia to satysfakcja z poszczególnych aspektów egzystencji człowieka, dla przykładu: pozycji społecznej, zdrowia, sposobu spędzania wolnego czasu oraz egzystencji jako całości.

Ostatecznie poziom życia wiąże się z potrzebami materialnymi (to have), jakość życia określa potrzeby pozamaterialne (to love oraz to be). Różnica między poziomem życia a jakością życia sprowadza się zatem do różnego rozłożenia akcentów na subiektywne i obiektywne czynniki, łącząc czynniki obiektywne z poziomem życia, a subiektywne z jakością życia [Sekuła-Kwaśniewicz, 2011, s. 11]. Im bardziej przykładamy wagę do warunków życia, obiektywnych wskaźników mierzalnych, takich jak liczba mieszkań na 1000 mieszkańców czy liczba km sieci kanalizacyjnej na 1000 mieszkańców, tym bardziej skupiamy się na poziomie życia w sensie obiektywnym. Podczas gdy jakościowe „miękkie” wskaźniki określają indywidualne odczucia satysfakcji z poziomu własnego wykształcenia, pozycji zawodowej, zdrowia, skupiamy się wokół oceny jakości życia w sensie subiektywnym.

\subsubsection{Dobrobyt a dobrostan}

Kolejne kategorie stanowiące o jakości życia to dobrobyt, najkrócej opisujący dobry byt materialny (obiektywny wymiar jakości życia) oraz dobrostan - dobry stan ducha (psychiki, subiektywny wymiar jakości życia) [Ostasiewicz, 2004, s. 11]. Dobrobyt to inaczej ogólna sytuacja materialna, na którą składają się: poziom uzyskiwanych dochodów, warunki bytowe (w tym mieszkaniowe, dostęp do bieżącej wody, kanalizacji, posiadanie i korzystanie z telefonu komórkowego, komputera i Internetu itp.).

Dobrostan (indywidualny) łączy się z odczuwanym poczuciem własnej wartości (dobre samopoczucie, dobre zdrowie, satysfakcja z życia, poczucie spełnienia w rodzinie i związku).

W uproszczeniu: Jakość życia = dobrobyt + dobrostan. Jednocześnie dobrobyt człowieka nie zależy jedynie od osiąganego dochodu. Do oceny jakości życia potrzebne jest nowe podejście, które za istotne uznaje sam sposób dochodzenia do wysokiego poziomu dochodu, np. posiadane wykształcenie, które determinuje podjęcie pracy o dochodzie satysfakcjonującym według indywidualnej, subiektywnej oceny. Współczesne rozumienie dobrobytu jednostki to „poziom realnego dochodu, majątku = ogólny dostatek ekonomiczny oraz poczucie bezpieczeństwa ekonomiczno-społecznego" [Aksman, 2010, s. 143]. Dobrobyt ekonomiczny w tym rozumieniu łączy się ze statusem społecznym, który można określić za pomocą zatrudnienia i uzyskiwanego z tego tytułu wynagrodzenia, zapewnieniem ochrony zdrowia na odpowiednim poziomie, zabezpieczeniem społecznym, poziomem wiedzy i wykształcenia. Aby uzyskać pełen obraz jakości życia, należy łącznie rozpatrywać dobrobyt i dobrostan.

\subsubsection{Paradoks zadowolenia}

Analizując powiązania subiektywnego samopoczucia, zadowolenia i obiektywnych warunków bytowych (materialnych), należy podkreślić istotność względnego poczucia pokrzywdzenia (WPP), przejawiającego się w:

- opinii grupy, która twierdzi, że znajduje się w bardziej niekorzystnej sytuacji w stosunku do innych. Najbardziej obiektywnie pokrzywdzonymi grupami nie są te, które czują się pokrzywdzone, ponieważ poczucie krzywdy zależy od tego, z kim te grupy się porównują (funkcja zawiści), 
- luce między aspiracjami (spodziewaną satysfakcją) a rzeczywistymi osiągnięciami. Im mniejsza luka, tym większa subiektywna jakość życia, mimo niekiedy bardzo niskiego poziomu jakości życia w sensie obiektywnym [Ostasiewicz, 2004, s. 68-69].

Wobec tego obiektywnie złe warunki bytowe i jednocześnie subiektywnie odczuwana wysoka satysfakcja (zadowolenie) z życia rodzi pewien rodzaj sprzeczności nazywany „paradoksem zadowolenia” [Łuszczyk, 2013, s. 156-157]. Należy jednak zaznaczyć, że zjawisko to nie jest długotrwałe i stanowi jedynie stan przejściowy, kiedy człowiek przystosowując się do złych warunków bytowych, wyznaje przekonanie o posiadaniu pewnych możliwości poprawy swojej sytuacji ekonomicznej, jednak wraz z upływem czasu przy utrzymujących się złych warunkach materialnych pogłębia się przygnębienie i rosnące niezadowolenie z życia, dochodząc do skrajnego przypadku tzw. deprywacji, gdy obiektywnie złym warunkom bytowym towarzyszy również indywidualnie odczuwane złe samopoczucie.

\subsection{Czynniki kształtujące jakość życia w mieście}

Podejmując się analizy czynników kształtujących jakość życia w mieście, należy odnieść się do definicji jakości życia dotyczącej sposobu realizacji zadań, względnie planów życiowych [Leźnicki, 2011, s. 214]: To, w jaki sposób jakość życia jest przez poszczególnych ludzi postrzegana, zależy od wielu czynników społeczno-gospodarczych, stanowiących o charakterze danego miejsca (miasta), ale także, a może przede wszystkim, od pożądanego stopnia zaspokojenia potrzeb materialnych i niematerialnych. System wartości decyduje o tym, co społeczeństwo akceptuje, m.in.: sposób dochodzenia do władzy, bogacenia się w danym środowisku, jako kluczowy element decyduje o wyborze odpowiednich zadań rozwojowych, indywidualnie dobranych i dostosowanych do potrzeb i możliwości danego człowieka. Potrzeby wyższego i niższego rzędu natomiast wynikają także z własnych, indywidualnych oczekiwań, przyjętych celów i dostępnych możliwości. To one ostatecznie odgrywają decydującą rolę w określeniu czynników wpływających na jakość życia. To jednostka wybiera sobie zestaw potrzeb niezbędny dla niej w danym miejscu i czasie, dlatego poziom zaspokojenia potrzeb będzie indywidualny dla każdego [Kaleta, 1988; Borowicz, 1988]. Odniesienie do przestrzeni i miejsca, w jakim rozpatrywana jest jakość życia, prezentuje definicja Światowej Organizacji Zdrowia (WHO) z 1993 r.: „postrzeganie przez jednostki jej pozycji w życiu, w kontekście kultury i systemów wartości akceptowanych przez społeczeństwo, w jakich żyje, oraz w relacji do jej celów życiowych, oczekiwań, zainteresowań". Wobec tego jakość życia to „zespół czynników przestrzenno-środowiskowych, produkcyjnych i kulturowych, składających się na rzeczywistość, w której człowiek żyje" [Otok, 1987, s. 79] (tab. 2.3).

Samo określenie własnej sytuacji, pozycji dokonuje się wobec powszechnie podzielanych i przekazywanych norm i wartości, które wynikają z głębszego kontekstu kulturowego, społecznego i gospodarczego (rys. 2.1).

Poczucie jakości życia może również wynikać z porównania sytuacji konsumentów opisywanego w ramach tzw. funkcji zawiści: stosunek różnicy między optymalnymi, znanymi i bezpośrednio dostępnymi jednostce warunkami życia a realnie istniejącymi warunkami życia, w których jednostka funkcjonuje [Kiełczewski, 2008, s. 288-289]. Aspekty obiektywne i subiektywne, zewnętrzne i zewnętrzne muszą być powiązane ze sobą z punktu widzenia wewnętrznej zgodności i komplementarności (wzajemnego uzupełniania się). 


\begin{tabular}{|c|c|c|}
\hline Czynnik & Zewnętrzne & Wewnętrzne \\
\hline Gospodarczy & $\begin{array}{l}\text { llość kapitału zewnętrznego inwesty- } \\
\text { cyjnego } \\
\text { Rozwój infrastruktury transportowej } \\
\text { w Polsce (drogownictwo i transport } \\
\text { publiczny) }\end{array}$ & $\begin{array}{l}\text { Poziom zatrudnienia i bezrobocia, } \\
\text { w tym bezrobocia długotrwałego } \\
\text { Mobilność zawodowa i przed- } \\
\text { siębiorczość mieszkańców } \\
\text { Koszty prowadzenia działalności } \\
\text { gospodarczej }\end{array}$ \\
\hline Społeczny & $\begin{array}{l}\text { Dostępność edukacji stopnia wyższego } \\
\text { i kształcenia ustawicznego } \\
\text { Sytuacja na rynku nieruchomości: ceny } \\
\text { mieszkań na rynku wtórnym i pierwot- } \\
\text { nym, dostępność kredytów mieszkanio- } \\
\text { wych }\end{array}$ & $\begin{array}{l}\text { Oferta kulturalna miejskich instytucji } \\
\text { kultury i oferta infrastruktury spor- } \\
\text { towej } \\
\text { Zabezpieczenie opieki zdrowotnej } \\
\text { - w tym usług bezpłatnych }\end{array}$ \\
\hline Środowiskowy & $\begin{array}{l}\text { Międzynarodowy i krajowy sytem } \\
\text { ochrony przyrody: normy imisji i emisji } \\
\text { zanieczyszczeń do środowiska } \\
\text { Obszary chronione i cenne przyrodniczo }\end{array}$ & $\begin{array}{l}\text { Stan środowiska przyrodniczego, } \\
\text { w tym zanieczyszczenia, poziom } \\
\text { hałasu } \\
\text { Lokalny system gospodarki } \\
\text { odpadami, w tym niebezpiecznymi, } \\
\text { m.in. azbest }\end{array}$ \\
\hline Świadomościowy & $\begin{array}{l}\text { Promocja miast w mediach, np. Łódź } \\
\text { kreuje } \\
\text { Ogólnospołeczna świadomość ekolog- } \\
\text { iczna: ogólnoposkie kampanie/programy } \\
\text { promujące zdrowy tryb życia }\end{array}$ & $\begin{array}{l}\text { Atrakcyjność historyczna } \\
\text { miejskiej przestrzeni centrum } \\
\text { Świadomość ekologiczna } \\
\text { mieszkańców }\end{array}$ \\
\hline Instytucjonalny & $\begin{array}{l}\text { Realia polityki krajowej: system } \\
\text { i sposób sprawowania władzy } \\
\text { Rozwój infrastruktury kulturalnej } \\
\text { i ochrona dziedzictwa kulturowego }\end{array}$ & $\begin{array}{l}\text { Poziom zaufania do władz } \\
\text { lokalnych } \\
\text { Zaspokajane potrzeby mieszkańców } \\
\text { w ramach granic administracyjnych } \\
\text { miast i stref podmiejskich } \\
\text { Aktywność mieszkańców i władz } \\
\text { lokalnych w realizacji projektów } \\
\text { Budżetów Obywatelskich }\end{array}$ \\
\hline
\end{tabular}




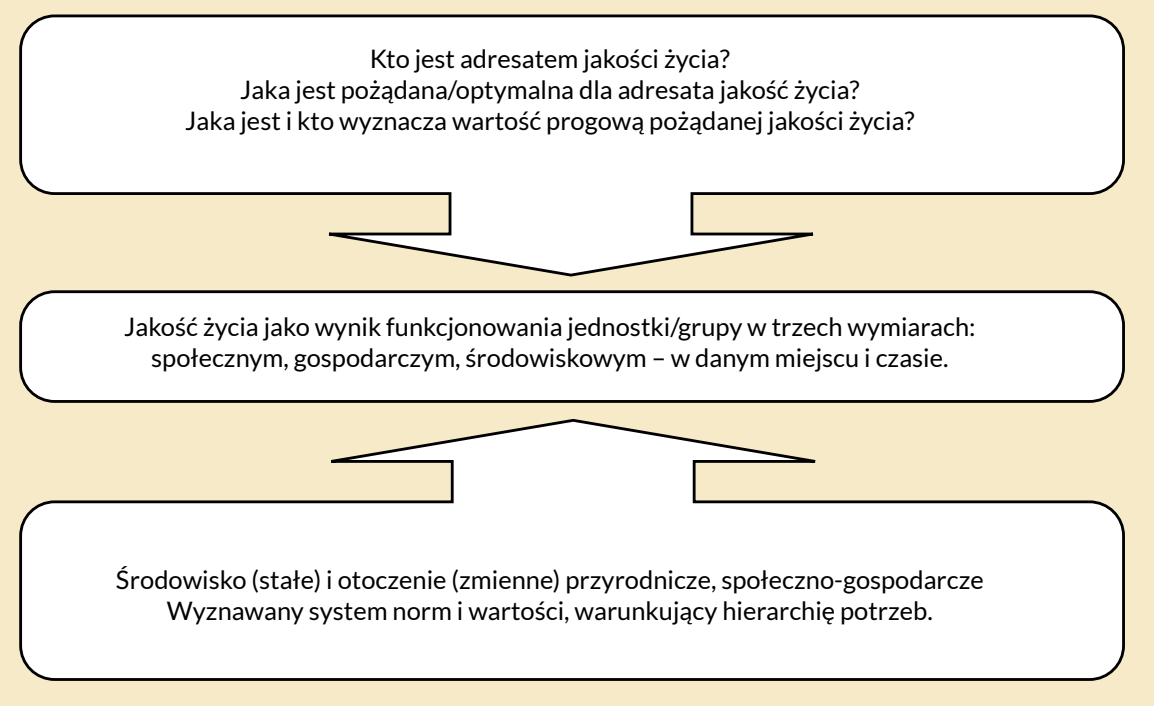

Źródto: opracowanie wtasne na podstawie: Borys, 2004; Borys, Rogala, 2008; Żliç, 2007; Leźnicki, 2011; Rokicka, 2013.

\subsection{Pomiar jakości życia}

Kontrowersje wokół pomiaru jakości życia wynikają bezpośrednio z wielowątkowości pojęcia oraz jej wielowymiarowego charakteru. Samo podejście do badania jakości życia nie może skupiać się tylko wokół sfery globalnej [Felce, Perry, 1995]. Współcześnie różne dziedziny życia zajmują różne miejsce w globalnej jakości życia. Aby przejść do bezpośrednich przykładów pomiarów jakości życia w mieście (w ujęciu lokalnym), należy zadać pytanie o ich celowość: po co badać jakość życia mieszkańców miasta i jakie korzyści mogą przynieść miastu wyniki? Badanie jakości życia w miastach bowiem:

a) daje informacje zarządzającym, czy miasto rozwija się w zaplanowanym kierunku, w tempie zadowalającym;

b) stanowi podstawę identyfikacji barier rozwojowych i aktualizacji istniejących strategii rozwoju miasta;

c) jest sposobem komunikacji na linii urząd miasta - mieszkańcy i zachęcania ich do działań lokalnych;

d) stanowi podstawę oceny osiągnięć władz miasta, i uklasowania go w rankingu miast na tle regionu (jako narzędzie promocji i przyciągania inwestorów, w przypadku wysokiego miejsca w rankingu) [Kusterka, Rogala, 2006; Rogala, 2009].

Subiektywna ocena mieszkańców daje władzom wiedzę na temat nastrojów społecznych, ich oczekiwań względem poczynionych inwestycji i kierunków rozwoju, daje także możliwość porównania opinii różnych grup, np. badanie jakości życia mieszkańców Krakowa i Poznania w 2012 r., badanie poziomu zadowolenia mieszkańców z życia w Sopocie, badanie opinii mieszkańców Gliwic i Jaworzna o stanie miasta, warunkach życia oraz oczekiwaniach wobec władz miejskich. 
Wskaźniki obiektywne są zwykle liczone na podstawie danych statystycznych, m.in.: Bank Danych Regionalnych i baz danych opracowanych przez Urząd Miasta. Często wskaźniki „miejskie” opracowywane są przy okazji tworzenia strategii rozwoju.

W badaniu cech subiektywnych wykorzystuje się najczęściej metodę badań ankietowych, w której kluczowe znaczenie mają:

- dobór próby badawczej, reprezentatywność próby;

- konstrukcja kwestionariusza: kafeteria pytań, jego długość, precyzja i obiektywizm;

- realizacja badania, rola ankietera oraz analiza i interpretacja wyników.

Przykładowe zestawienie wskaźników subiektywnych i obiektywnych dotyczących wybranej kategorii jakości życia (tab. 2.4).

Tabela 2.4. Wybrane wskaźniki subiektywne i obiektywne dotyczące zdrowia

\begin{tabular}{|l|l|}
\hline \multicolumn{1}{|c|}{ Wskaźniki subiektywne } & \multicolumn{1}{|c|}{ Wskaźniki obiektywne } \\
\hline $\begin{array}{l}\text { Czy uważa sie Pani/Pan za osobę } \\
\text { cieszącą się dobrym zdrowiem } \\
\text { Jak Pani/Pan ocenia jakość usług } \\
\text { służby zdrowia? }\end{array}$ & $\begin{array}{l}\text { Liczba praktyk lekarskich na 1000 mieszkańców } \\
\text { Liczba mieszkańców na jedną przychodnię (jednego } \\
\text { lekarza) } \\
\text { Liczba aptek na 1000 mieszkańców } \\
\text { Osobodni leczenia na 1000 mieszkańców } \\
\text { Wydatki na ochronę zdrowia ogółem } \\
\text { na 1 mieszkańca } \\
\text { Wydatki majątkowe na ochronę zdrowia na 1 miesz- } \\
\text { kańca }\end{array}$ \\
\hline
\end{tabular}

Źródto: Rogala, 2009, s. 42.

Całościowe podejście do pomiaru jakości życia wymaga konieczności uzupełnienia obiektywnych wskaźników (mierzalnych za pomocą dostępnych danych statystycznych) wskaźnikami subiektywnymi, związanymi z odczuciami, ocenami w badaniach ankietowych.

W Unii Europejskiej realizowane są trzy rodzaje badań tj. Europejskie Badanie Jakości Życia, Europejskie badanie dochodów i warunków życia krajów Unii Europejskiej (EU-SILC) oraz badania jakości życia w miastach europejskich w ramach Programu Urban Audit.

1. Europejskie Badanie Jakości Życia - realizowane przez Fundację na rzecz Poprawy Warunków Życia i Pracy (Eurofound powołaną przez Komisję Europejską). Główne obszary badania dotyczą: zatrudnienia i warunków pracy, równowagi pomiędzy życiem osobistym i zawodowym, relacji przemysłowych i partnerstwa, spójności społecznej. Założenia badania odwołują sie do integralności trzech sfer życia: „mieć, być i kochać” według 12 obszarów/dziedzin jakości życia, dając łącznie 161 wskaźników w następujących kategoriach: zdrowie, zatrudnienie, ubóstwo dochodowe, edukacja, rodzina, partycypacja w życiu wspólnoty i społeczeństwa, mieszkalnictwo, środowisko, transport, komunikacja, bezpieczeństwo, czas wolny, satysfakcja z życia.

2. Europejskie badanie dochodów i warunków życia krajów Unii Europejskiej (EU-SILC) w Polsce realizowane i publikowane przez Główny Urząd Staty- 
styczny. Główne obszary badań stanowią źródło danych z zakresu sytuacji dochodowej, ubóstwa i innych warunków życia ludności. Metodą badania jest bezpośredni wywiad z respondentem - dobrowolne, reprezentacyjne badanie ankietowe prywatnych gospodarstw domowych.

Badanie według Modułu EU-SILC „Dobrobyt” 2013 w Polsce objęło wszystkie osoby w wieku 16 lat i więcej, będące aktualnymi członkami gospodarstw domowych, w których realizowane było badanie EU-SILC. W badaniu EU-SILC 2013 zestaw zmiennych dotyczących dobrobytu obejmował: szeroko rozumianą satysfakcję (poziom zadowolenia) z m.in.: sytuacji finansowej gospodarstwa domowego, warunków mieszkaniowych, relacji z innymi ludźmi, zadowolenia z aktualnej pracy, okolicy miejsca zamieszkania (wyk. 2.1).

Jakość życia jest kategorią stopniowalną na skali 0-10, wobec czego grupowanie odpowiedzi nastąpiło według schematu:

0-3 - ocena negatywna;

4-6 - ocena pośrednia (ani dobra, ani zła);

7-10 - pozytywna ocena zjawiska.

Według respondentów w ostatnich latach satysfakcja z poszczególnych składowych jakości życia sukcesywnie malała, największe spadki odnotowano w kategorii „Sytuacja finansowa gospodarstw domowych”. Warto zwrócić uwagę na związek spadku poziomu zadowolenia z „Sytuacji finansowej gospodarstw domowych" ze spadkiem „Ogólnego poziomu zadowolenia z życia” i łagodniejsze spadki oceny zadowolenia z "Relacji z innymi” czy „Czasu na wykonywanie ulubionych czynności, co w pewnym stopniu można tłumaczyć omawianym zjawiskiem paradoksu zadowolenia.

\section{Wykres 2.1. Poziom satysfakcji z warunków bytowych wg Modułu EU-SILC „Dobrobyt”}

\section{3 w Polsce}

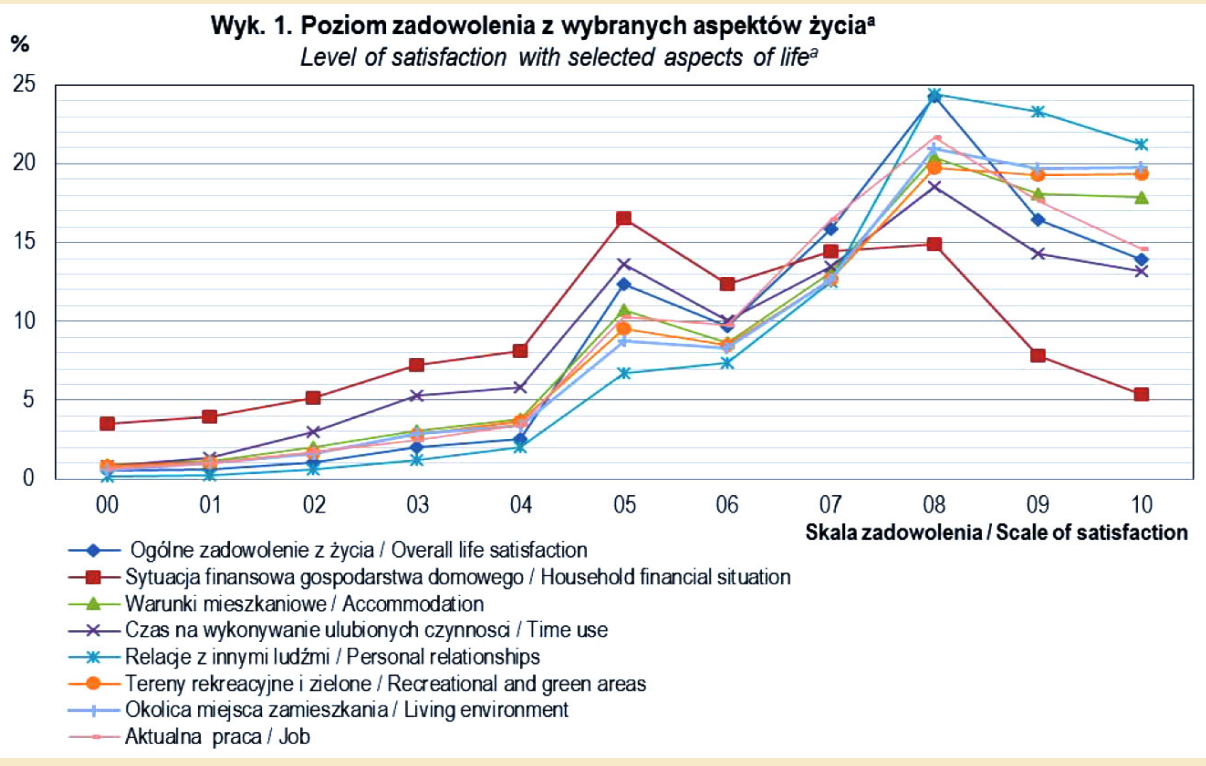

Źródto: Raport z badania EU-SILC 2013, s. 200-201. 
3. Badania jakości życia w miastach europejskich w ramach Programu Urban Audit Realizowane jako wspólne przedsięwzięcie: Komisji Europejskiej, Dyrekcji Generalnej ds. Polityki Regionalnej Unii Europejskiej oraz Urzędu Statystycznego Wspólnoty Europejskiej - Eurostat, który jest koordynatorem wszystkich prac.

Wykonawcami programu są krajowe urzędy statystyczne (www.stat.gov.pl), urzędy miast i samorządy terytorialne. Celem badania jest zdobycie porównywalnych danych statystycznych, dotyczących warunków życia w miastach europejskich. Dane dotyczą m.in.: demografii, struktury gospodarstw domowych, rynku pracy, edukacji czy ochrony zdrowia itp.

Dodatkowo zbierane są informacje dla funkcjonalnych stref miejskich (obszarów faktycznego oddziaływania miasta) oraz obszarów wewnątrzmiejskich, które mają służyć pogłębionej analizie zjawisk społeczno-gospodarczych. Stworzenie takiej bazy danych ma pozwolić władzom miast na porównania, wymianę doświadczeń w realizacji inwestycji czy usprawnić funkcjonowanie i zarządzanie usługami publicznymi [Borys, Rogala, 2008].

Urban Audit w swej podstawowej wersji koncentruje się na obiektywnej jakości życia w miastach, określanej w Polsce najczęściej warunkami/poziomem życia. Charakter uzupełniający dla informacji uzyskanych w tym programie mają wskaźniki subiektywnej jakości życia (zadowolenia, satysfakcji z życia i różnych jego aspektów).

1) Badanie subiektywnej jakości życia będące dopełnieniem/uzupełnieniem wskaźników obiektywnych stanowił wywiad telefoniczny, w każdym mieście wśród wylosowanych min. 300 respondentów, udzielając w nim 23 pytań dotyczących m.in.: Czy jest Pan/Pani bardzo zadowolony(a), raczej zadowolony(a) czy zupełnie niezadowolony(a) z takich usług publicznych, jak:

- komunikacja miejska (autobusowa, tramwajowa, metro?

- edukacja?

- usługi medyczne świadczone przez szpitale?

- usługi medyczne świadczone przez lekarzy?

- dostęp do terenów zielonych, parków, zieleni miejskiej? itd.

2) Badanie obiektywnej jakości życia w ramach programu Urban Audit obejmują dane dla 28 wskaźników z 9 działów [Borys, Rogala, 2008, s. 23-31]:

- demografia (32 wskaźniki, 11\%),

- aspekty społeczne (31 wskaźników, 11\%),

- aspekty ekonomiczne (66 wskaźników, 23\%)

- zaangażowanie/aktywność obywatelska (22 wskaźniki, $8 \%$ ),

- edukacja i wykształcenie (19 wskaźników, 7\%),

- środowisko (58 wskaźników, 20\%),

- podróże i transport (24 wskaźniki, 8\%),

- społeczeństwo informacyjne (15 wskaźników, 5\%),

- kultura i rekreacja (19 wskaźników, 7\%).

Wybrany wskaźnik mówiący o jakości życia mieszkańców polskich miast w kontekście sytuacji mieszkaniowej, zatem w wymiarze społeczno-gospodarczym (tab. 2.5).

Określenie pozycji w rankingu daje stwarza możliwość:

- porównań miast w odniesieniu do sytuacji mieszkaniowej, z uwzględnieniem najszybszego tempa zmian w ramach polityki mieszkaniowej władz lokalnych;

- określenia trendów związanych z sytuacją mieszkaniową na przestrzeni lat bazowych 2001, 2004, 2008, 2011, co daje informację władzom lokalnym na temat konieczności podejmowania kolejnych działań na rzecz poprawy dostępności mieszkań o wyższym standardzie oraz stanu mieszkań socjalnych itp. 
Tabela 2.5. Wskaźnik sytuacji społeczno-gospodarczej w badaniu URBAN-AUDIT polskich miast dla lat bazowych 2001, 2004, 2008, 2011

\begin{tabular}{|c|c|c|c|c|}
\hline \multirow{2}{*}{$\begin{array}{l}\text { Miasto w granicach } \\
\text { administracyjnych }\end{array}$} & \multicolumn{4}{|c|}{ Mieszkania pozbawione podstawowych wygód } \\
\hline & 2001 & 2004 & 2008 & 2011 \\
\hline Warszawa & 35711 & 32642 & 27899 & 22940 \\
\hline Łódź & 57467 & 56904 & 50059 & 43100 \\
\hline Kraków & 14040 & 12960 & 12312 & 7429 \\
\hline Wrocław & 25587 & 24936 & 17700 & 16335 \\
\hline Poznań & 17374 & 16679 & 10581 & 9594 \\
\hline Gdańsk & 16689 & 16281 & 8837 & 10592 \\
\hline Szczecin & 18863 & 18486 & 12665 & 11789 \\
\hline Bydgoszcz & 16887 & 16637 & 11225 & 12594 \\
\hline Lublin & 10233 & 9884 & 8416 & 7701 \\
\hline Katowice & 16931 & 16677 & 11125 & 11395 \\
\hline Białystok & 4835 & 4528 & 4194 & 3817 \\
\hline Kielce & 5883 & 5721 & 4227 & 4218 \\
\hline
\end{tabular}

Źródto: Tablica 1., bttp://stat.gov.pl/statystyka-regionalna/ badania-regionalne/ urban-audit-250/.

Z kolei ranking stolic europejskich (tab. 2.6) stanowi uzupełnienie Komisji Europejskiej do badania Urban Audit z 2012 r., prezentując ogólną satysfakcję z życia, dzieląc ją na cztery kategorie: satysfakcję mieszkańców z ich miast, wyobrażenia mieszkańców na temat ich miast, środowisko, osobistą sytuację mieszkańców.

Warto zwrócić uwagę na ostatnie miejsce Aten, które w wyniku negatywnych skutków kryzysu finansowego odczuły radykalnie pogorszenie jakości życia mieszkańców. Należy przypomnieć 2004 r., kiedy to Polska, wstępując do Unii Europejskiej, pod kątem mobilności ludzi młodych, poziomu wykształcenia, dochodów i możliwości spędzania wolnego czasu, zdecydowanie odbiegała od takich europejskich stolic, jak Londyn, Ateny, Madryt czy Paryż. Obecne badania pokazują, iż sytuacja ta uległa odwróceniu, dając Warszawie 15. miejsce w rankingu stolic UE, na równi z Dublinem. 
Tabela 2.6. Ogólna satysfakcja z życia w europejskich stolicach UE w 2012 r. według danych Komisji Europejskiej

\begin{tabular}{|c|c|}
\hline Miasto & Całkowita zgoda (\%) \\
\hline Kopenhaga & 97 \\
\hline Amsterdam & 96 \\
\hline Stockholm & 96 \\
\hline Wiedeń & 95 \\
\hline Luxemburg & 95 \\
\hline Berlin & 93 \\
\hline Wilno & 93 \\
\hline Zagrzeb & 92 \\
\hline Helsinki & 92 \\
\hline Lizbona & 92 \\
\hline Praga & 90 \\
\hline Dublin & 90 \\
\hline Warszawa & 90 \\
\hline Lubliana & \\
\hline
\end{tabular}

\begin{tabular}{|c|c|}
\hline Miasto & Całkowita zgoda (\%) \\
\hline Tallin & 89 \\
\hline Paryż & 89 \\
\hline Valletta & 88 \\
\hline Lefkosia & 87 \\
\hline Madryt & 87 \\
\hline Londyn & 87 \\
\hline Bratysława & 86 \\
\hline Bruksela & 84 \\
\hline Sofia & 84 \\
\hline Ryga & 84 \\
\hline Budapeszt & 83 \\
\hline Bukareszt & 82 \\
\hline Rzym & 80 \\
\hline Ateny & 52 \\
\hline & 8013, \\
\hline & 84 \\
\hline
\end{tabular}

Źródto: Quality of Life..., 2013, s. 25.

Polskie doświadczenia w zakresie pomiaru jakości życia skupiają się współcześnie wokół statystyki publicznej, badań rządowych i badań komercyjnych. Najistotniejsze z punktu widzenia przydatności wyników i dostępności danych są obecnie Diagnozy społeczne o warunkach i jakości życia Polaków - badanie realizowane na zlecenie Ministerstwa Pracy i Polityki Społecznej przez zespół ekspertów z użyciem danych Głównego Urzędu Statystycznego. Stanowi ono reprezentatywne, niezależne badanie sondażowe obiektywnej i subiektywnej jakości życia Polaków. Kolejne edycje przeprowadzono w latach: 2000, 2003, 2005, 2007, 2010, 2013, których każdorazowo efektem jest Raport z badań pt. Diagnoza społeczna - warunki i jakość życia Polaków. Dostępne dane z 2013 r. dokonują oceny jakości życia respondenta według kryterium płci i wieku, wykształcenia, statusu społeczno-zawodowego w ośmiu wymiarach życia, m.in.: poziomie cywilizacyjnym, dobrobycie materialnym, dobrostanie społecznym, patologii, kapitale społecznym, dobrostanie psychicznym, dobrostanie fizycznym, stresie życiowym [Diagnoza społeczna 2013, s. 426-445]. Wyniki stanowią analizę poszczególnych elementów jakości życia, tworząc ranking miast wraz ze zmieniajcą się sytuacją na przestrzeni trzech badanych lat (tab. 2.7).

Kolejnym, istotnym elementem badań nad jakością życia staje się współcześnie statystyka publiczna dotycząca głównie obiektywnej jakości życia, tj. danych obiektywnych, wskaźników mierzalnych publikowanych w rocznikach, w bankach danych - np. w Banku Danych Regionalnych, publikacjach GUS np. [Jakość życia, 2014]. Tu znaczącą rolę odgrywają dane dotyczące materialnych (sytuacji materialnej), 
jak i wybranych niematerialnych aspektów życia społeczeństwa, związane z sondażowymi badaniami budżetów gospodarstw domowych (BBGD) i badanie aktywności ekonomicznej ludności (BAEL).

Ostatnie ogniwo stanowią badania komercyjne jakości życia w polskich miastach, formułując wnioski bezpośrednio dla władz lokalnych, potencjalnych inwestorów zewnętrznych czy mieszkańców.

Ostatecznie, jakość życia jest kategorią złożoną i wielowątkową, co już na etapie jej definiowania nastręcza problemy i budzi szereg wątpliwości. Podstawą pomiarów jest umiejętność rozróżnienia zagadnień teoretycznych, m.in: poziom a jakość życia, dobrobyt a dobrostan oraz subiektywne i obiektywne rozumienie ilościowych i jakościowych wskaźników, uznanie ich komplementarności względem siebie dla pełnego obrazu jakości życia w mieście. Z kolei mnogość badań nad jakością życia w Polsce i w krajach Unii Europejskiej zarówno tych publicznych, jak i komercyjnych, posiada szczególną użyteczność z punktu widzenia planowania rozwoju społecznogospodarczego miast. Samo tworzenie rankingów powinno dawać możliwości nie tylko porównania się do tzw. Konkurencji, ale przede wszystkim wskazywać kierunki wzmacniania czynników rozwoju i poprawy jakości życia mieszkańców. Sam dostęp do dóbr i usług oraz wysoki poziom dochodów mieszkańców nie stanowi jeszcze o wysokiej jakości życia w mieście w ujęciu całościowym.

Tabela 2.7. Ogólny wskázilk jakości życia w wybranych polskich miastach

\begin{tabular}{|c|c|c|c|}
\hline \multicolumn{4}{|c|}{ Ranking miast* } \\
\hline 2013 & 2011 & 2009 & Miasto \\
\hline 1 & 2 & 1 & Toruń \\
\hline 2 & 1 & 2 & Warszawa \\
\hline 3 & 3 & 4 & Poznań \\
\hline 4 & 4 & 5 & Kraków \\
\hline 5 & 5 & 13 & Jaworzno \\
\hline 6 & 6 & 3 & Gdynia \\
\hline 7 & 17 & 10 & Olsztyn \\
\hline 8 & 10 & 6 & Gdańsk \\
\hline 9 & 11 & 7 & Gorzów Wielkopolski \\
\hline 10 & 7 & 9 & Szczecin \\
\hline & & & \\
\hline 18 & 12 & 17 & Łódź \\
\hline
\end{tabular}

*Ogólny wskaźnik jakości życia w przekroju większych miast reprezentowanych przez co najmniej 60 respondentów w latach 2009, 2011 i 2013 w całych próbach. 
Badanie dotyczyło zasobów kapitałowych polskich miast = obiektywnej jakości życia w ramach Raportu na temat wielkich miast Polski, tj.: Gdańska, Katowic, Krakowa, Łodzi, Poznania, Warszawy i Wrocławia [Raport..., 2007].

Dokonano w nim analizy potencjału rozwojowego miast, wyodrębniając 7 kapitałów składowych, w tym: Instytucje, Ludzie, Inwestycje, Wizerunek, Infrastruktura, Finanse i Jakość życia (ich obiektywnych wskaźników - statystyka publiczna). Wartości wskaźników znormalizowano, tj. średni poziom każdego = 100, co dało możliwość porównań. Przy średnim poziomie dla 7 miast równym 100, Kapitał Jakości Życia w Łodzi wynosi 89. Z czego wśród składowych można wyodrębnić:

a) jakość środowiska naturalnego - 106,

b) poczucia bezpieczeństwa - 98,

c) jakość edukacji - 70,

d) jakość opieki zdrowotnej - 80 .

Wartością dodaną Raportu, prezentującego wyniki badania, jest wskazanie inspiracji dla poprawy jakości życia w wybranym mieście. Dla przykładu, Łódź postawiono przed wzorem: Zurych - miasto, które od kilku lat znajduje się w czołówkach rankingów w kategorii najlepsza jakość życia. Porównując oba miasta, wskazano wspólne punkty, określające kapitał rozwojowy miasta, a które warto w Łodzi udoskonalić na rzecz poprawy jakości życia mieszkańców. Łódź jawi się jako miasto o bogatych tradycjach przemysłu włókienniczego, ze zróżnicowaną ofertą kulturalną i edukacyjną, zwłaszcza w dziedzinie szkolnictwa wyższego. Zurych z kolei jest miastem, które mimo wysokiego stopnia urbanizacji (przemysł, koncentracja branży finansowej), dzięki wdrożeniu odpowiednich programów proekologicznych należy do najczystszych miast Europy. Zurych posiada bogatą ofertę turystyczną oraz kulturalną (50 muzeów, 100 galerii, liczne wystawy, koncerty itp.). Mieszkańcy mają zapewnioną szeroko rozwiniętą opiekę medyczną (na 1 lekarza przypada 435 osób). W mieście funkcjonuje 20 uczelni wyższych, a 30,1\% mieszkańców ma wyższe wykształcenie (średnio w Szwajcarii wskaźnik ten wynosi 21,5\%).

Źródto: opracowanie własne na podstawie Raport..., 2007, s. 14-17.

\section{Bibliografia}

Aksman E. (2010), Redystrybucja dochodów i jej wpływ na dobrobyt społeczny w Polsce w latach 1995-2007, Uniwersytet Warszawski, Warszawa.

Allardt E. (1976), Dimensions of welfare in a comperative Scandinvian study, „Acta Sociologica", vol. 19, no. 3.

Borowicz R. (1988), Równość i sprawiedliwość społeczna, PWN, Warszawa.

Borys T. (2004), Jakość, jakość życia oraz pojęcia i relacje pochodne, [w:] W. Ostasiewicz (red.), Ocena i analiza jakości życia, Wydawnictwo AE we Wrocławiu, Wrocław.

Borys T., Rogala P. (2008), Jakość życia na poziomie lokalnym - ujęcie wskaźnikowe, UNDP, Warszawa.

Diagnoza społeczna 2007. Warunki i jakość życia Polaków. Raport, Czapiński J., Panek T. (red.), Wyższa Szkoła Finansów i Zarządzania w Warszawie, Warszawa. 
Diagnoza społeczna 2013. Warunki i jakość życia Polaków. Raport, J. Czapiński, T. Panek (red.), Warszawa.

Eurofound (2014), Trzecie europejskie badanie jakości życia: różnice między obszarami miejskimi i wiejskimi, www.eurofound.europa.eu [dostęp 07.09.2015].

Famielec J. (1999), Straty i korzyści ekologiczne w gospodarce narodowej, Wydawnictwo PWN, Warszawa-Kraków.

Felce D., Perry J. (1995), Quality of life: its definition and measurement, „Research in Developmental Disabilities", vol. 16, no 1.

Gałęski B. (1977), Styl życia i jakość życia - próba systematyzacji pojęć, „Studia Socjologiczne", nr 1.

Galloway S., Bell D., Hamilton Ch., Scullion A. (2006), Quality of Life and Well-Being: Measuring the Benefits of Culture and Sport - A Literature Review, Scottish Executive Education Departament, Edinburgh.

Glatzer W. (2006), Conditions and criteria for improving quality of life, [w:] W. Ostasiewicz (ed.), Towards Quality of Life Imroviement, The Publishing House of the Wrocław University of Economics, Wrocław.

Jakość życia w Polsce (2014), GUS, Warszawa.

Kaleta A. (1985), Jakość życia mieszkańców wsi rejonu uprzemysłowionego, Wydawnictwo UMK, Toruń.

Kaleta A. (1988), Jakość życia młodzieży wiejskiej, Wydawnictwo UMK, Toruń.

Kiełczewski D. (2008), Konsumpcja a perspektywy zrównoważonego rozwoju, Uniwersytet w Białymstoku, Białystok.

Kusterka M., Rogala P. (2006), Wykorzystanie wskaźników jakosci życia na szczeblu lokalnym, [w:] E. Broniewicz (red.), Stan obecny i perspektywy rozwoju zrównoważonego, Wydawnictwo PB, Białystok.

Leźnicki M. (2011), Jakość życia jako przedmiot badań naukowych i refleksji, [w:] W. Tyburski (red.), Zasady kształtowania postaw sprzyjających wdrażaniu zrównoważonego rozwoju, Wydawnictwo Naukowe UMK, Toruń.

Łuszczyk M. (2013), Poprawa jakości życia w skali międzynarodowej, Fundacja Uniwersytetu Ekonomicznego w Krakowie, Kraków.

Monitorowanie jakości usług publicznych jako element zintegrowanego systemu zarzqdzania jednostkami samorządu terytorialnego (2012), Kraków-Poznań, wydanie elektroniczne.

Ostasiewicz W. (2004), Ocena i analiza jakości życia, Wydawnictwo AE we Wrocławiu, Wrocław.

Otok S. (1987), Geografia społeczna, PZLG, Warszawa, z. 2-3.

Quality of life in cities. Perception survey in 79 European cities, 2013, http://ec.europa. eu/regional_policy/activity/urban/audit/index_en.cfm [dostęp 20.08.2014].

Papuć E. (2011), Jakość życia - definicje i sposoby jej ujmowania, „Current Problems of Psychiatry", no 12(2).

Raport na temat wielkich miast polskich. Łódź (2007), PwC, Warszawa.

Raport z badania EU-SILC. Dochody i warunki życia ludności Polski (2014), www.stat. gov.pl [dostęp 08.09.2015].

Rogala P. (2009), Zaprojektowanie i przetestowanie systemu mierzenia jakości życia w gminach. Raport z realizacji pracy. Etap 2, Jelenia Góra-Poznań.

Rokicka E. (2013), Jakość życia - konteksty, koncepcje, interperetacje, [w:] J. Grotowska, E. Rokicka (red.), Nowy Ład? Dynamika struktur społecznych we współczesnych społeczeństwach. Księga pamiątkowa poświęcona Profesor Wielisławie Warzywodzie- 
-Kruszyńskiej z okazji 45-lecia pracy naukowej i dydaktycznej, Wydawnictwo UŁ, Łódź.

Sekuła-Kwaśniewicz H. (2011), Współczesne przeobrażenia turystyki a wybrane parametry jakości życia, [w:] M. Drużkowski (red.), Jakość życia - aspekty turystyczne i rekreacyjne, Wydawnictwo Abaton, Kraków.

Soziologie-Lexikon (1991), G. Reinhold (Hrsg), S. Lamnek, H. Recker, R. Oldenbourg Verlag, München-Wien.

Survey on perceptions of quality of life in 75 European cities (2007), European Commission, Brussels.

Szczech-Pietkiewicz E. (2012), Konkurencyjność wybranych polskich miast na tle miast z innych państw członkowskich Unii Europejskiej, „Zeszyty Naukowe Kolegium Gospodarki Światowej", nr 34.

WHOQOL (1997), Measuring Quality of Life, World Health Organization, Geneva.

Zadrożniak M. (2015), Środowisko przyrodnicze jako czynnik determinujacy poprawę jakości życia mieszkańców obszarów wiejskich w kontekście koncepcji zrównoważonego rozwoju, [w:] B. Bartniczak, K. Trzeciak (red.), Aktualne trendy w zarządzaniu środowiskiem, Uniwersytet Ekonomiczny we Wrocławiu, Jelenia Góra.

Żylicz T. (2007), Trwały rozwój w teorii ekonomii, [w:] B. Poskrobko (red.), Obszary badań nad trwałym i zrównoważonym rozwojem, Wydawnictwo Ekonomia i Środowisko, Białystok. 


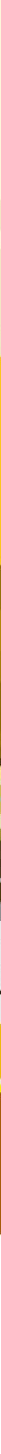

